\title{
Az ocsúdik ige etimológiája szlavisztikai megközelítésben
}

1. A m. ocsúdik (1508) 'ébred; magához tér' nyj. (1700) ocsul 'ua.' ige eredetére az eddigi szakirodalomban kétféle magyarázatot találunk. Az egyik elképzelés szerint az ige valamely török nyelvből került át a magyarba, a másik szerint belső fejlemény egy ismeretlen eredetü tőből. Ma már elmondhatjuk, hogy a török etimológia hangtani, alaktani és szemantikai megfontolások alapján tarthatatlan, míg a belső fejlődésen alapuló magyarázat megválaszolatlan kérdéseket hagy maga után. Jelen cikkemben röviden be szeretném mutatni a két említett etimológia gyenge pontjait, s egy harmadik, szláv eredetmagyarázatra szeretném felhívni az olvasók figyelmét.

2. Mielött górcső alá vennénk a két eddigi elméletet, tisztázzuk a szó - pontosabban: az ocsúdik és ocsul szavak - első előfordulásának idejét és helyét; szükségünk lesz ezekre az adatokra a tanulmány további részeiben.

Az ocsúdik szavunk 1508-tól ismert meg igekötős alakban, s a Nádor-kódex a legkorábbi forrása (TESz. 2: 1066), 1. meg vLodotvolna (NádK. 1185 [a kódex 594. oldala]). A Debreceni kódexben (1519 k.) már a mai, megszokott formájában adatolt a szó: fel oLuduan (DebrK. 361 [161]). A korai adatok közül még az Érdykódexbelit (1527) érdemes megadni: uchwdeek (ÉrdyK. 77 [51]), wchwdnanak (ÉrdyK. 161 [448]; ez utóbbi adatot a NySz. hibásan közli: „wchodnanak”). Az ocsul szóalak jóval későbbi, mert csak 1700-ra tehető első előfordulásának ideje. Az 1700-as adat Gyöngyösi István Budán kiadott Charicliáját jelenti, ahol az ocsul ugyancsak igekötős alakban fordul elö (1. az először 1700-ban, Lőcsén kiadott mủ 1763-as kiadásának 21. lapján: fel ócsóltam). Itt érdemes megjegyezni, hogy Gyöngyösi mủvében megtaláljuk az ocsúdik igét is (Gyöngyösi 1763: 22, 30: ocsódék; az adatokat a NySz. 3: 1096 alapján idézem), ami azt jelzi, hogy a két ige egy bizonyos időszaktól kezdve egyidejü használatban volt ugyanabban a jelentésben, ugyanazon a nyelvterületen.

A rend kedvéért említsük meg, hogy az ocsúdik szó kimutathatóan írók, illetve költők, például Baróti Szabó Dávid és Csokonai Vitéz Mihály nyelvhasználata révén emelkedett irodalmi nyelvi szintre (TOLNAI 1929: 98; TECHERT 1936: 247-248).

3. Török eredetről először VÁMBÉRY (1870: 166) írt, aki az ujg. otuk 'éber', otukluk 'éberség' szavakkal hozta az ocsúdik szót összefüggésbe, később pedig K. PALló (1976: 339-340, 1982: 141-142) rokonította azt a török nyelvekben széles körben elterjedt $a c ̌$ - 'nyit, tár stb.' (a további jelentéseket és szóalakokat 1. ĖSTJa. 209-210; TLH. 2: 1214-1217) igével. E két feltevésnek azonban túl sok hangtani, alaktani és időrendi szépséghibája volt ahhoz, hogy megállják a helyüket, s ezért későbbi tanulmányokban és etimológiai szótárakban negatív kritikával kellett szembenézniük. VÁMBÉRY ötletének alapvető jellegü hibáira három évvel később BUDENZ (1873: 106-107) mutatott rá. (Még ha a jelen cikk szerzője nem

Magyar Nyelv 112. 2016: 295-306. DOI: 10.18349/MagyarNyelv.2016.3.295 
is ért egyet BUDENZ végkövetkeztetéseivel - erröl bővebben később -, VÁMBÉRY kritikájában igaza van.) K. PALLÓ $(1976,1982)$ gondolatát az EWUng. (2: 1054) és a nemrég megjelent TLH. (2: 1217) értékelték valószínütlennek (mindkét szótár az 1982-es monográfiában változtatások nélkül megismételt eszmefuttatásra hivatkozik csak). Mivel a két eredeztetési kísérlet közül csak a későbbi felel meg a tudomány mai módszertani elvárásainak, tegyük félre VÁMBÉRY ötletét, és foglalkozzunk röviden K. PALLó magyarázatával.

A magyar etimológiai szótárak szerzői véleménye szerint az ocsúdik és ocsul igékben a - $d$ és $-l$ nem a szótő részei, hanem képzők, melyek gyakorító jelentést kölcsönöznek a két szóalaknak. A TLH. kritikája erre alapozódott: RÓNA-TAS ANDRÁS szerint ha egy török $a c ̌$ - 'nyit, tár' metaforizált jelentésből indulnánk ki, mint ahogy azt K. PALLÓ szerette volna, akkor a magyarba átvett szó jelentése inkább 'pislog' kellene, hogy legyen. Egy ilyen feltevésben, természetesen, nincs is semmi rossz, azonban emlékeznünk kell arra, hogy a szemantikai változásokat és továbbfejlődéseket előre látni rendkívül nehéz, és az ilyen jellegủ argumentumok mindig erősen megkérdőjelezhetők lesznek. Ezen kívül érdemes megemlíteni, hogy ha hiányoljuk a gyakorító jelentést abból, ami hipotetikusan fejlődhetett volna egy török 'nyit, tár' jelentésủ igéből, akkor úgyszintén hiányolni kellene a gyakorító jelentést a létező 'ébred, magához tér' jelentésből. Úgy érzem, hogy ami K. PALLÓ $(1976,1982)$ magyarázatát igazán gyengíti - a szemantikai hiányosságokon kívül -, az az, hogy amely nyelvi adatokra a törökségi nyelvekben hivatkozott, azok vagy összetett szavak, mint pl. a kirg. ujku ač- '1. álmot üz; 2. kialussza magát' (1. KirgRS. 81, aч- a.), melyekben a szemantikai töltet nem az $a \check{c}$ - igében, hanem az azt megelőző nomenben van, vagy pedig a török nyelvekben széles körben elterjedt - $l$ szenvedő képzős szenvedő igealakok, mint pl. az oszm. (tör.) açıl- 'magához tér stb.' (1. TürS. 10), csuv. uśal- 'gyógyul stb.' (1. AšMARIN 1929: 309-311), míg a magyar „megfelelőknek” nincs egyértelmüen szenvedő igei jelentésárnyalatuk (az ocsúdik és ocsul mediális igei természetủek). Az ocsúdik ige amúgy sem tartozhatna a kora ómagyar kori szenvedő értelmü ikes igék csoportjába (pl. törik, hallik, érzik, látszik, tetik), mert azok tranzitív igékből fejlödhettek csak (1. TNyt. II/2: 302-303).

Ettől függetlenül egyet kell értenünk a TLH. szerzőivel abban, hogy a török etimológia ma már nem tủnik valószínünek, s mindenképpen helyes döntés volt, hogy az ocsúdik a TLH.-ban az Improbable etymologies c. fejezetben került elemzésre. A szócikk végkövetkeztetése az, hogy el kell fogadnunk az EWUng. (2: 1054) véleményét, mely szerint a szó ismeretlen eredetü, fiktív tő származéka.

A TLH. megjelenésével a szó török etimológiája körüli vitát lezártnak tekinthetjük.

4. Térjünk át a másik eredetmagyarázatra, miszerint az ocsúdik és ocsul szóalakok belső fejlemények. Ezt az elképzelést a TESz. (2: 1066), az EWUng. (2: 1054) és ESz. (2006: 583) nagyjából ugyanúgy foglalja össze (a rend kedvéért megjegyzem, hogy BÁRCZI GÉZA [SzófSz. 221] a szót ismeretlen eredetűnek tartja). E szótárak szerint az ocsúdik és ocsul igék egy ismeretlen szócsalád gyakorító képzős tagjai, azzal a kikötéssel, hogy nem tudjuk megállapítani, hogy a felté- 
telezett fiktív tövük (fiktív tövű származékként kezeli a szót BENKŐ 1984: 120 is) névszói vagy igei jellegü volt-e (TESz. 2: 1066).

Az alapszó szófaji hovatartozásával kapcsolatos kétségek szemmel láthatóan onnan erednek, hogy a szóban forgó - $d$ már a korai ómagyar korban alapvetően deverbális verbumképző, míg az - $l$ denominális igeképző volt (1. TNyt. I: 83-84, II/1: 99, 102). S bár képzőink funkcionális disztribúciója az ómagyar korban körvonalazódik, a - $d$ esetében elmondható, hogy nem képezhetett nomenből igét, az -l-ről pedig tudjuk, hogy nem képzett igéből igét (1. TNyt. I: 77). Ez az első nehézség, amellyel a belső fejlődésen alapuló szómagyarázatnak szembe kell néznie.

Mindkét képzőről egyébként elmondhatjuk, hogy teljes és csonka tövekhez egyaránt járulhatott. A - $d$ már a korai ómagyar korban improduktív, az -l produktivitása pedig erősen korlátolt és a késő ómagyar korban játszott fontos szerepet a jövevényigék meghonosításában (1. TNyt. I: 83, 84; II/1: 68, 82, 96-97). Mindez azt mutatja, hogy a fenti források szerzői a két szót vagy nagyon korai átvételnek tekintik egy azonosítatlan idegen nyelvből, vagy az öröklött szókincs részeként kezelik.

Ez utóbbival kapcsolatos a belső fejlődésen alapuló etimológia másik gyenge pontja, mégpedig az, hogy nincs mihez kötni az ocs(ú)- fiktív tövet az uráli nyelvcsaládon belül. A 'pelyva stb.' jelentésủ m. ocsú (1. TESz. 2: 1066; TLH. 2: 626629) ilyen értelemben természetesen nem jöhet számításba. BUDENZ (1863: 338 339) azon alapuló érvelése, hogy a 'felébred' jelentésủ igék hangfestő eredetüek lehetnek, és ,annak a bizonyos ásítozási hangnak visszahangoztatását” tükrözik, „melyet nem ritkán, kivált kelletlen fölkelés mellett, a fölébredők szoktak ejteni”, nehezen mondható meggyőzőnek. (BUDENZ itt török nyelvekből idéz példákat, és - ma már tudjuk: helytelenül - a magyar ún-nal és ocsódni-val veti őket össze.) $\mathrm{S}$ bár rokon szavak hiánya alapján nem vethetünk el egy eredetmagyarázatot, az ilyen jellegü izoláltság szembetünő hiányossággá válik akkor, amikor egy alaktani és hangtani szempontból áttekinthető és erős filológiai alapokon nyugvó konkurens etimológiával szembesítik őket.

Márpedig a szláv eredeztetés ilyen megalapozott etimológiának tủnik.

5. Máris az elején jegyezzük meg, hogy KNIEZSA ISTVÁN (1955) alapmüvében a szót nem találjuk meg. Az ocsúdik igét a szakirodalomban legutoljára MAREK STACHOWSKI (2014) említette a TLH.-t bemutató recenziós cikkében az alábbi kontextusban: „The authors rightly dismiss Tkc. [= Turkic - N. M.] ač- 'to open' as an etymological source of Hung. ocsúdik. [...] In this context, I would like to call attention to another fact: The verb for 'revive' in Polish is ocucić (i.e. with a voiceless [-ucić]). It is only in South Poland, certain parts of which (e.g. Orawa) belonged to Hungary in the past, that this verb is pronounced ocudzic (with voiced [-uźićc]), see SEJP [= BorSEJP. - N. M.] 88. How do Polish dial. ocudź- and Hung. ocsúd- compare?". STACHOWSKI tehát azt sugallja, hogy a magyar és a lengyel szó hasonló alakja és hasonló jelentése átvétellel magyarázható. Nem pontosítja azonban az átadás irányát.

A lengyel szóalak magyar eredete az alábbi bekezdésekben felsorakoztatott szláv adatok fényében kevésbé valószínü. Azonban a m. ocsúdik ige esetleges szláv eredetének ilyen megfogalmazása is több szempontból megkérdőjelezhető. 
Elsősorban meg kell említeni, hogy noha az ocudzić szóalak ismert egyes Krakkótól délre és attól északkeletre fekvő területeken (Nowy Targ és Lublin környékén, 1. JANASIŃSKI 1886: 186; ŁOPACIŃSKI 1899: 812), az Árva- és Szepes-vidéki lengyel nyelvjárásokban már nem jegyzik (1. KarSGP. 3: 386; SGP. 4: 526-527; FITAK 1997, 2004, 2007; KĄŚ 2003, 2011) és előfordulása az egész lengyel nyelvterületen rendkívül ritka. Ennek fényében több mint valószínü, hogy igazuk van az ún. Varsói szótár szerzőinek, amikor a le. nyj. ocudzić szóalak zöngés palatális zárréshangjáról azt állítják, hogy az egész lengyel nyelvterületen ismert ocucić 'éleszt, magához térít' ocucić się 'felocsúdik, magához tér' és a vele szinte egyjelentésü obudzić 'ébreszt' obudzić się 'ébred, feleszmél' ige keveredéséből származik (SW. 3: 557). Nyelvföldrajzilag tehát a szóban forgó szóalak nem köthető konkrét nyelvterülethez (a kontamináció bárhol létrejöhetett) és ritka.

Másrészt ha a magyar igét lengyel eredettel szeretnénk magyarázni, és a le. -ć- és a m. - $d$ - közötti fonetikai különbséget egy le. nyj. -ź-vel szeretnénk áthidalni, akkor a magyar szó 1508-as előfordulása fényében találnunk kellene olyan ó- vagy középlengyel adatot, melyben a mai lengyel nyelvjárásokból ismert második szótagbeli 3 kimutatható lenne. Ilyenre példát azonban nem találunk a rendelkezésünkre álló szótárakban, lásd SStp. (1: 333, cucenie a.; 5: 406-407, ocucenie, ocucić (się) a.; 7: 108, przecucić a.), SPXVI. (20: 32-33, ocucić, ocucić się, ocucony a.), LINDE (2/1: 410, ocknać a.), SWil. (1: 833), ami talán közvetetten azt mutatja, hogy az ocucić és az obudzić igék esetleges keveredése új keletü jelenség lehetett. De még ha találnánk is ilyen 15-16. századi lengyel adatot, akkor nehéz lenne választ adni arra kérdésre, hogy a le. -ź- helyén miért lett a magyarban elsősorban - $d$-, és nem -gy-? Ritkán előfordul a tájnyelvben m. fölocsógyik fölocsúgyik is (ÚMTsz. 2: 382), de a rendelkezésünkre álló történeti adatok világosan mutatják a -gy- másodlagosságát.

E helyütt lábjegyzetszerủen talán érdemes megjegyezni, hogy a második szótagbeli le. $c>\mathrm{m}$. $c s$ hanghelyettesítés nem lenne akadálya egy ilyen etimológiának: a 16. századi lengyel nyelvemlékekben találunk példát olyan szóalakokra is, melyekben a szóban forgó második szótagbeli -c- helyén - $c$ - áll (1. SPXVI. 20: 32-33: oczucić). De *oczudzić alakban a szó nem fordult elö soha.

A közvetlen lengyel átvétel gondolatát gyengíti továbbá az a tény is, hogy a magyar és lengyel együttélés sohasem öltött nagy méreteket a történelmi Magyarország északi vagy Lengyelország déli területein. A magyarság közvetlenül inkább csak szlovák nyelvü lakossággal érintkezett, s érintkezésük vonala a 16-18. században Árva vármegyétől délre és délkeletre húzódott, Gömör és Kis-Hont vármegyében, valamit Szepesben (1. KNIEZSA 1941: 287), ennél északabbra pedig már nem tolódott el. Ez megmutatkozik abban is, hogy a magyar nyelv lengyel jövevényszavainak száma elenyésző, elsősorban müszavak vagy kultúrszavak, s szófaji hovatartozásukat tekintve kizárólag névszók (igei átvétel általában erős befolyásra vall; a kérdéskörhöz 1. pl. BÁRCZI 1958: 92-93; TÖRÖK 2007). A lengyel nyelvjárások magyar jövevényszavainak nagy többsége esetében pedig szlovák közvetítést kell feltételeznünk (ez különösképpen igaz a korábbi átvételekre, 1. NÉMETH 2009: 10-16). Szlovák közvetítés azonban az ocsúdik és ocsul igék esetében nem jöhet számításba, mivel a le. ocucić cucić ige etimológiai megfe- 
lelői az irodalmi szlovákban ocitnút' sa 'feleszmél, ismeretlen helyen találja magát' és cítit' 'érez; megérez, sejt' (1. HSSJ. 1: 191, 3: 108; SSJ. 1: 173-174), egy a szlk. - $i$ - helyén - $u$-t tartalmazó és a magyar $-d$-t kellőképpen magyarázó alakot pedig nem tudunk kimutatni a szlovák nyelvjárásokból. ${ }^{1}$ E tekintetben a jelen cikk következő részében bemutatott cseh alakok sem jöhetnek számításba mint közvetítőként (bár ez nyelvföldrajzi megfontolásból is elvethető lenne). A közvetlen magyar átvételek száma a lengyel nyelvjárásokban csak a 18. század végétől nő - elsősorban a magyar nyelvü államigazgatásnak, később pedig a magyar nyelvü oktatásnak köszönhetően -, azonban a magyar nyelv lengyel jövevényszavairól ugyanez nem mondható el.

6. Nézzünk azonban körül a lengyel ocucić etimológiai megfelelői háza táján. A szó minden valószínüség szerint az ősszl. *otjutiti '(újra) érez, eszméletét visszaszerzi' szó leszármazottja, mely a *jutiti 'érez, érzékszerveivel érzékel, észrevesz' ige *ot elöljárós alakja (1. ĖSRJa. 3: 179, очyтиться a.; SłSEJP. 1: 108, сисіс́ a.; BorSEJP. 379, ocucić a.; DERKSEN 2008: 381; az ĖSSJa. és a SłPsł. nem jutott el még az *otjutiti szócikkig). Az eredeti prepozíció (vö. pl. ószl. оштоүтттн, 1. ĖSRJa. 3: 179) szótagja nem minden szláv szóalakban őrződött meg, minthogy az eredeti összláv morfémahatárok elmosódása után $(o t+j->o c-, o c$-, $o c ́$ - $)$ hibásan $o$ prepozíciós igeként érzékelték az igét a nyelvhasználók. Ez megtörtént a lengyel nyelvben is (vö. le. ocucić cucić), de ugyanez mondható el a cseh, a szlovák és a délszláv megfelelők esetében is (ez utóbbi nyelvterületen az $o$-val kezdődő alakok jóval ritkábbak), vö. pl. ócs. cútiti, cs. cítit 'érez, érzékel', ócs. octnúti sě, cs. oc(i)tnouti se 'feleszmél, ismeretlen helyen találja magát', szlk. cítit' 'érez; megérez, sejt', ocitnút' sa 'feleszmél, ismeretlen helyen találja magát', h. ćutjeti, oćutjeti 'érez', oćućivati '(iter.) érez' (1. MACHEK 1968: 87-88, cititi a.; SS. 4: 255; HSSJ. 1: 191, 3: 108; RHiSJ. 8: 535, 536-537; ERHiSJ. 1: 367-368, ćutjeti a.). Az ukránban csak az очутитися '1. észhez tér, feleszmél; 2. lelki egyensúlyt visszanyer' szóalakot említi a szótárirodalom (SUM. 5: 836), a szó eleji o- elhagyására ebben a nyelvben nem találtam példát (a SSuM.-ban nem találjuk meg ezt a szót).

$\mathrm{Az}$ eddig felsorakoztatott szóalakokat azonban ugyanazon érvek alapján el kellene vetnünk a magyar ocsúdik ige lehetséges forrásaként, mint azt a le. ocucić nyj. ocudzić esetében tettük: a m. $-d$-t nehéz lenne bármelyikükből is (ti. egy -t-ből vagy -ć-ből) megmagyarázni. Szerencsénkre azonban a 16. és 17. századi oroszból ismert a mai or. очутиться 'megkerül, ismeretlen helyen találja magát' olyan alakváltozata is, melyben a szótő - $t$-je helyén - $d$ áll. Ez az очюдитися '1. magához tér, felocsúdik; 2 . felébred; 3 . valahova kerül' szó, mely очутитися $\sim$ очютитися alakban is használatban volt az említett időszakban (1. SRJaXVI-XVII. 14: 105-106). Ezen keleti szláv alakkal már több sikerrel magyarázható a m. ocsúdik ige, hiszen hangalakjukat és jelentésüket tekintve nagyon közel állnak egymáshoz. A fent említett mediális igék a 16. és 17. századi o. очутити очютити '1. érez; 2. észrevesz, meglát; 3. megért, felismer' tranzitív igealakok (1. SRJaXVI-XVII.

${ }^{1}$ Összesen több mint negyven kisebb-nagyobb szlovák nyelvjárási és irodalmi nyelvi szótárt néztem át. A fontosabbak közül a következöket említeném csak meg: SSN., SSJ. (2: 468), BAKOŠ (1994), KRET (1994), FeKeTE (1995), HABOVŠTIAK (1995), HodOROVSKÝ (1997), VS., JelEŇOVÁ (2011). 
14: 105-106) továbbképzett alakjai, és a m. ocsúdik valójában mind a mediális очюдитися, mind a tranzitív *очюдити igealakból kifejlödhetett, bár a k. szl. очюдитися szemantikai közelsége miatt némiképp meggyőzőbb forrásnak tünik.

Érdemes itt megjegyezni, hogy a szláv morfémahatárok pontos azonosítása, vagyis az infinitivuszi -iti, illetve -iti sja leválasztása és magyar képzővel való helyettesítése jól ismert mechanizmus a magyar jövevényigék esetében. Minthogy az ocsúdik ige mediális jelentésü (a cikkünkben feltételezett szláv etimonhoz hasonlóan) és egy bizonyos állapotban való leledzést fejez ki, ha valóban szláv átvétel, akkor természetes módon az ikes igék rendszerébe kellett kerülnie. Ezt lehetővé tette természetesen az, hogy az ikes ige alaki kitevője ebben a szerepében - vagyis mint a mediális és történést kifejező igenem kitevője - eleven maradt a kései ómagyar korban is (1. TNyt. II/1: 217).

7. Ha tehát a m. ocsúdik igét egy szláv, pontosabban k. szl. *očuditi (sja) átvételeként szeretnénk magyarázni, az ellen kevés hangalaki vagy szemantikai kivetnivalót lehetne előhozni. A korai adatokban tapasztalható első két szótagbeli $o-\dot{u}(u)$ (1. DebrK.), $u-o ́$ (o) (1. NádK.) és $u-u ́(u)$ (1. ÉrdyK.) váltakozás hangátvetéssel és hasonulással magyarázható, bár elképzelhető az is, hogy a szl. $u$ hang kettős jellegü meghonosításából fakad (vö. szl. $u>$ m. $u \sim o$; 1. pl. HELIMSKI [STACHOWSKI] 2009: 89), a variánsok kialakulását pedig befolyásolhatta az ómagyar kori $u>o$ nyíltabbá válási tendencia is. Az ocsúdik hosszú ú-ját (és a hosszú $o$-t az ocsódik-féle alakokban, 1. TESz) körülményes a szláv etimonnal magyarázni, még ha az $u$ hangsúlyos helyzetben is állt a feltételezett átadó alakban, valamint egyes nyelvészek szerint a pannóniai szláv nyelvjárás(ok)ban az ősszl. $u$ reflexe hosszú $\bar{u}$ volt (1. CHELIMSKIJ 1988: 353). A hosszúság itt másodlagosnak tủnik, kialakulhatott például a vajúdik-féle, illetve az -ódik képzős szóalakok mintájára is, vö. pl. a vajúdik szó 1456 körüli szóalakjának második szótagbeli ó-ját is (EWUng. 1598: vaÿozi, mely a szó első előfordulási adata is egyben). A hosszúság másodlagossága ellen nem vall az említett három legkorábbi adatat sem, hiszen a Nádor-, a Debreceni és az Érdy-kódexben a másolók írásban vagy nem különböztették meg a rövid és hosszú $o-o ́, u-u$ hangpárokat, vagy a jelölés messze nem volt következetes (1. pl. KNIEZSA 1952). Így például a Nádor-kódexben, ahol a hosszú magánhangzókat a másoló „meglehetős következetességgel betükettőzéssel jelöli” (NádK. 19), a meg vLodotvolna írásmód inkább rövid magánhangzós ejtésre mutat.

8. A szláv etimológiát valamelyest gyengíti az a tény, hogy egy 16. századi vagy akár 15. századi szláv átvétel esetében feltűnő, ha a magyarban hiányzik benne a megszokott - $l$ képzö (1. pl. TNyt. II/1: 49; az ocsul-ban ugyan megvan, de az egy jóval későbbi alak). Az -l jövevényszó-honosító képzőről legújabban elmondható, hogy lemaradhatott, de csak a korai jövevényigékről (1. ZOLTÁN 1999: 59, 2014: 212).

De talán épp ez a titok nyitja? Elképzelhetö, hogy az ocsúdik is egy korai keleti szláv átvétel (vagyis a szlávok azon csoportjától vettük át, amelyekkel kapcsolataink a leghosszabb múltra tekintenek vissza), és koraisága miatt épülhetett be tőalakban a magyar igei rendszerbe, úgy, ahogy az a k. szl. *styditi 'megszégyenít, 
gyaláz, szid'> m. szid és a szl. měriti 'mér' > mér esetében is megtörtént (1. pl. ZOLTÁN 2014: 212). Az említett két szemléltető példa közül az első azért is érdekes párhuzam, mert a *styditi alakról ZOLTÁN ANDRÁs (1999: 58) egyértelmüen kimutatta, hogy csak a keleti szláv nyelvekből ismert 'megszégyenít, gyaláz, szid' jelentésben, s ezért azt is - az *očuditi (sja)-hoz hasonlóan - a szlávságnak csak ezen csoportjától vehettük át. (A mér ige esetében pedig a keleti szláv eredetet kizárni nem lehet, igaz annak kizárólagosságát sem lehet bebizonyítani - mint azt már megszokhattuk szláv eredetü szavaink nagy többségénél.)

Azonban - s jegyezzük meg ezt világosan - bár a „korai átvétel” pontos időrendi határa nincs megszabva, és a szavak írott nyelvemlékekben való előbukkanásának ideje nem jelent egyet azok létrejöttének vagy meghonosodásának idöpontjával, az ocsúdik ige 1508-as első előfordulása nem támogatja egyértelmüen a fent bemutatott elképzelést. Összehasonlításul: a szid ige első előfordulásának ideje 1315 k., míg a mér igéé 1372 u./1448 k. (1. pl. TESz. 3: 747; 2: 897).

Érdemes megemlítenünk annak lehetőségét is, hogy az -l-, jövevényszavak meghonosításában részt vevő képző produktivitása esetleg nem (csak) időhöz volt kötve, hanem nyelvterülethez is, és a jövevényigék tőalakban való meghonosításának mechanizmusa a keleti szláv nyelvekkel érintkező területeken hosszabb ideig eleven maradt. Ezt azonban konkrét nyelvi anyag nem bizonyítja, s ezért tisztán hipotetikus kiindulású feltevés marad.

Végül elképzelhető, hogy a honosító képző mellőzésének okát az ige mediális természetében és az ezzel összefüggő ikesedésben kell keresni. ${ }^{2}$

9. Az ocsúdik ige szláv eredetmagyarázatának erős pontja - a hangalaki és jelentéstani egybeeséseken kívül - az, hogy nem kényszerít minket arra, hogy az ocsúdik - $d$-jét képzőként kezeljük, hanem azt a szláv szótő részeként tekinthetjük (1. a fent említett feltételezett *ocsú- alapszó szófaji hovatartozásával kapcsolatos kétségeket). Ezen etimológia azonban nem ad egyszerü magyarázatot arra, hogy milyen viszonyban áll az 1700-tól adatolt ocsul és az ocsúdik ige. Az ocsul ige ugyanis közvetlenül egy szláv *očuditi *očutiti alak átvételeként nem magyarázható hangtani okok miatt; egy - $l$ képzős alak valószínüleg *ocsúdol lenne. Kettős átvételről tehát itt nem lehet szó.

Ami az ocsul-ról elmondható, az az, hogy sokkal ritkábban használt alak lehetett. Ezt mutatja a történelmi adatok kis száma (1. Ok1Sz., NySz., SzT., TESz. stb.) valamint az, hogy a mai nyelvjárásokban is jóval ritkább az ocsul (1. ÚMTsz. 4: 159, 3: 346, ahol csak egy nyelvi példát találunk rá; az MTsz. 2: 1569 pedig egyáltalán nem jegyez ocsul alakot). E megvilágításban elképzelhetőnek tűnik, hogy az ocsul alak magyar tájnyelvi talajon alakult ki az ocsúdik-ból, a morfémahatárok téves értelmezése mellett, s a képzőnek hitt - $d$-t (vö. hazud hazudik) helyettesítette a csonka tövekhez is járulható -l. Nem kizárt, hogy ez utóbbi folyamatot katalizálhatta a már fentebb említett vajúdik (1456 k.) '1. nélkülöz, szükséget lát; 2 . fárad, gyengül; 3 . a szülést megelőző hosszas kínlódáson megy át' vajul (1567-1576) '1. fárad, gyengül; 2. a szülést megelőző hosszas kínlódáson

${ }^{2}$ Ez utóbbi észrevételt a szerkesztőségtől kapott egyik lektori véleményben olvashattam. E kiegészítésért ezúton szeretnék köszönetet mondani. 
megy át' (TESz. 3: 1071) kettős alakhasználat mintája. Mi több, az ocsul szóalak létrejöttéhez hozzájárulhatott az állapotváltozást kifejező mediális igék mintája, amilyen például az ájul vagy fajul.

10. Ha igaz az állítás, hogy az ocsúdik szláv jövevényszó, akkor ezáltal tovább bővülne a magyar szókincsben eddig belső fejleménynek hitt vagy ismeretlen fiktív tőből magyarázott szavak köre, amelyekről az utóbbi kutatásoknak köszönhetően kiderült, hogy szláv átvételek, lásd például a darázs szó etimológiáját (ZOLTÁN 2010, 2015; NÉMETH 2011). Újabban L'UBOR KRÁLIK (2014) javasolt szláv etimológiát a m. vizsga és vizsgál magyarázatára, ami azért is érdekes, mert BENKÖ (1984: 120) egymás mellett említette a vizsgál és ocsúdik igéket mint fiktív tőből képzett szavakat.

Kulcsszók: etimológia, magyar etimológia, szláv etimológia, szláv jövevényszavak a magyarban, jövevényigék honosítása.

\section{Rövidítések}

cs. $=$ cseh; csuv. $=$ csuvas; $\mathbf{h} .=$ horvát; iter. $=$ iteratív; k. szl. = keleti szláv; kirg. = kirgiz; le. $=$ lengyel; $\mathbf{m} .=$ magyar; $\mathbf{n y j .}$ = nyelvjárási; ócs. $=$ ócseh; ószl. = ószláv; or. $=$ orosz; oszm. $=$ oszmán; ősszl. = ősszláv; szl. = szláv; szlk. = szlovák; tör. $=($ törökországi) török; ujg. $=$ ujgur.

\section{Hivatkozott irodalom}

AŠMARIN, NiKOLAJ IVANOVIČ 1929. Thesaurus linguae Tschuvaschorum. Slovaŕ čuvašskogo jazyka 3. Narodnyj komissariat po prosveščeniju Čuvašskoj Avtonomnoj Sovetskoj Socialističeskoj Respubliki, Kazań-Čeboksary.

BAKоŠ, SAMKO 1994. Krátky slovník nárečia slovenského Gemerského. Print-Servis, Rybník-Bratislava.

BENKÖ LORÁND 1984. A magyar fiktív (passziv) tövü igék. Akadémiai Kiadó, Budapest.

BorSEJP. = BORYŚ, WIESŁAW 2005. Stownik etymologiczny języka polskiego. Wydawnictwo Literackie, Kraków.

BUDENZ JÓZSEF 1863. A török hangutánzó igékröl. Nyelvtudományi Közlemények 2: 338361.

BUDENZ JÓZSEF 1873. Jelentés Vámbéry Ármin magyar-török szóegyezéseiröl. Nyelvtudományi Közlemények 10: 67-135.

ChelimskiJ, EvgeniJ Arnoĺdovič [= Helimski, Eugen] 1988. Vengerskij jazyk kak istočnik dlja praslavjanskoj rekonstrukcii i rekonstrukcii slavjanskogo jazyka Pannonii. In: TOLSTOJ, NIKITA IĹIČ szerk., Slavjanskoe jazykoznanie. 10 Meždunarodnyj s"ezd slavistov. Sofija, sentjabŕ 1988 g. Doklady sovetskoj delegacii. Nauka, Moskva. 347-368.

DebrK. $=1997$. Debreceni kódex, 1519. A nyelvemlék hasonmása és betühü átirata . Előkész. ABAFFY CSILLA - REMÉNYI ANDREA, bev. MADAS EDIT - REMÉNYI ANDREA. Régi Magyar Kódexek 21. Magyar Nyelvtudományi Társaság - Argumentum, Budapest, 1997. 
DERKSEN, RICK 2008. Etymological Dictionary of the Slavic Inherited Lexicon. Brill, Leiden-Boston. http://dx.doi.org/10.15388/baltistica.50.1.2245.

ERHiSJ. = SKOK, PETAR 1971-1974. Etimologijski rječnik hrvatskoga ili srpskoga jezika 1-4. Jugoslavenska Akademija Znanosti i Umjetnosti, Zagreb.

ESz. = Etimológiai szótár. Magyar szavak és toldalékok eredete. Főszerk. ZAICZ GÁBOR. Tinta Könyvkiadó, Budapest, 2006.

ÈSRJa. = VASMER, MAX 1986-1987. Etimologičeskij slovaŕ russkogo jazyka 1-4. TRUBAČEV, OLEG NIKOLAEVIČ fordításában és kiegészítéseivel. [Hasonmás kiadás: Izdateĺstvo Astreĺ, Moskva, 2004.]

ÈSSJa. = Ètimologičeskij slovaŕ slavjanskich jazykov. Praslavjanskij leksičeskij fond 1-36. [A-Otъgrěbati.] Főszerk. TrubaČEV, OleG NiKOLAEVIČ - ŽURAVLEV, ANATOLIJ FEDOROVIČ. Izdateĺstvo Nauka, Moskva, 1974-2010.

ÈSTJa. = SEVORTJAN, ÈRVAND VLADIMIROVIČ 1974. Ėtimologičeskij slovaŕ tjurkskich jazykov (obščetjurkskie i mežtjurkskie osnovy na glasnye). Izdateĺstvo Nauka, Moskva.

EWUng. = Etymologisches Wörterbuch des Ungarischen 1-2. Föszerk. BENKÖ LORÁND. Akadémiai Kiadó, Budapest, fószerk. 1993-1995.

ÉrdyK. = Érdy codex. Közzéteszi VOLF GYÖRGY. Nyelvemléktár 4-5. MTA Nyelvtudományi Bizottsága, Budapest, 1876.

FEKETE, JÁN 1995. Krátky slovník nárečia slovenského Modrokamenského. Print-Servis, Modrý Kameň.

FITAK, FRANCISZEK 1997. Słownik gwary orawskiej. Wydawnictwo Ryszard M. Remiszewski - RMR, Gliwice.

FITAK, FRANCISZEK 2004. Słownik gwary spiskiej. Ośrodek Kultury Turystyki Górskiej PTTK w Pieninach, Szczawnica.

FITAK, FRANCISZEK 2007. Gwara podhalańska, orawska i spiska. Słownictwo wybrane. Ośrodek Kultury Turystyki Górskiej PTTK w Pieninach, Szczawnica.

Gyöngyösi István 1763. Új életre hozatott Chariclia, avagy a Chariclia ritka példájú, és olvasásra kedvet adó historiának némelly régi versek rongyábúl, és azoknak sok fogyatkozásibul újjabb, ás jobb rendben vétele... Landerer Ferenc Leopold, Buda.

HABOvŠTIAK, ANTON 1995. Krátky slovnik nárečia slovenského Oravského. Print-Servis, Krivá-Bratislava.

Helimski [= ChelimskiJ], Eugen 2009. 1. Stachowski, MAREK 2009.

HodorovsKÝ, JozeF 1997. Malý Spišský slovník. Mesto Spišská Nová Ves, Spišská Nová Ves.

HSSJ. = Historický slovník slovenského jazyka 1-6. [A-V.] Főszerk. MAJTÁN, MiLAN. Veda, Bratislava, 1991-2005.

JANASIŃSKI, IGNACY 1886. Jasełka w mieście Grybowie. Zbiór Wiadomości do Antropologji Krajowéj 10: 169-186.

JELEŇOVÁ, DARINA 2011. Novol'ubovniansky goralský nárečový slovník. Novolubovniansko-slovenský a slovensko-novolubovniansky. K. n., h. n.

ŁOPACIŃSKI, HIERONIM 1899. Przyczynki do nowego słownika języka polskiego. Prace Filologiczne 5/3: 681-976.

KarSGP = KARŁOWICZ, JAN 1900-1911. Słownik gwar polskich 1-6. Polska Akademia Umiejętności, Kraków.

KĄŚ, JÓZEF 2003. Słownik gwary orawskiej. Księgarnia Akademicka, Kraków. 
KĄŚ, JÓZEF 2011. Słownik gwary orawskiej 1-2. Księgarnia Akademicka, Kraków.

KirgRS. = JUDACHIN, KONSTANTIN KUŹMIČ 1965. Kirgizsko-russkij slovaŕ. Izdateĺstvo «Sovetskaja Ènciklopedija», Moskva.

KNIEZSA ISTVÁN 1941. Zur Geschichte der ungarisch-slowakischen ethnischen Grenze. Archivum Europae Centro-Orientalis 7/1-3: 240-309.

KNIEZSA ISTVÁN 1952. Helyesirásunk története a könyvnyomtatás koráig. Nyelvészeti Tanulmányok 2. Akadémiai Kiadó, Budapest.

KNIEZSA IsTVÁN 1955. A magyar nyelv szláv jövevényszavai 1/1-2. Akadémiai Kiadó, Budapest.

KRÁLIK, L’UBOR 2014. Ungarisch vizsga, vizsgál: Versuch einer slawischen Etymologie. Studia Etymologica Cracoviensia 19: 205-210.

KRET, ANTON 1994. Krátky slovník nárečia slovenského Spišského. Print-Servis, Spišská Nová Ves - Smižany - Bratislava.

Linde, SAMUEL Bogumił 1807-1814. Stownik języka polskiego 1-6. Drukarnia XX. Piiarów, Lwów.

MACHEK, VÁCLAV 1968. Etymologický slovník jazyka českého. Československá akademie věd, Praha.

MTsz. = Magyar tájszótár 1-2. Szerk. SzINNYEI JÓZSEF. Hornyánszky Viktor Akadémiai Könyvkereskedése, Budapest, 1893-1901. [Hasonmás kiadás: Nap Kiadó, Budapest, 2003.]

NádK. = Nádor-kódex (1508). A nyelvemlék hasonmása és betühü átirata bevezetéssel és jegyzetekkel. Közzéteszi PuszTAI IsTVÁN. Régi Magyar Kódexek 16. Magyar Nyelvtudományi Társaság, Budapest, 1994.

NÉMETH, MichA£ 2009. Zapożyczenia węgierskie w gwarze orawskiej i drogi ich przenikania. Księgarnia Akademicka, Kraków.

NÉmeth, MichaŁ 2011. The Hungarian and Slavonic Background of Bashkir ty̆raž 'wasp'. Studia Etymologica Cracoviensia 16: 93-101.

NySz. = SZARVAS GÁBOR - SIMONYI ZSIGMOND 1890-1893. Magyar nyelvtörténeti szótár a legrégibb nyelvemlékektöl a nyelvújításig 1-3. Hornyánszky Viktor, Budapest.

OklSz. = Magyar oklevél-szótár. Gyüjt. SzAmota István, szerk. ZolnAi GyUlA. Hornyánszky Viktor, Budapest, 1902-1906. [Hasonmás kiadás: Állami Könyvterjesztő Vállalat, Budapest, 1984.]

K. Palló Margit 1976. Ocsúdik. Magyar Nyelv 72: 339-340.

K. Palló Margit 1982. Régi török eredetü igéink. Studia Uralo-Altaica 1. József Attila Tudományegyetem, Szeged.

RHiSJ. = DANIČIĆ, ĐURO - MARETIĆ, TOMO 1880-1976. Rječnik hrvatskoga ili srpskoga jezika 1-23. Jugoslavenska Akademija Znanosti i Umjetnosti, Zagreb.

SGP. = Słownik gwar polskich 1-8. [A-Gościnka.] Szerk. KARAŚ, MIECZYSŁAW - REICHAN, JERZY - OKONIOWA, JoAnNA. Instytut Języka Polskiego Polskiej Akademii Nauk, Kraków, 1979-2013.

SłSEJP. = SŁAWSKI, FRANCISZEK 1952-1975. Słownik etymologiczny języka polskiego 1-6. [A-Łątka.] Towarzystwo Miłośników Języka Polskiego, Kraków.

SłPsł. = Słownik prasłowiański 1-8. [A-Gyža.] Főszerk. SŁAWSKI, FRANCISZEK. Wydawnictwo Polskiej Akademii Nauk, Wrocław-Warszawa-Kraków, 1974-2001. 
SPXVI. = Słownik polszczyzny XVI wieku 1-36. [A-Roztryknąć.] Főszerk. BĄK, STANISŁAW. Wydawnictwo Polskiej Akademii Nauk, Wrocław-Warszawa-Kraków, 1966-2014.

SRJaXVI-XVII. = Slovaŕ russkogo jazyka XI-XVII vv. 1-28. [A-Sulebnyj.] Főszerk. BARCHUDAROV, STEPAN GRIGOŔEVIČ et al. Izdateĺstvo Nauka, Moskva, 1975-2008.

SS. = Staročeský slovník 1-26. [N-Při.] Főszerk. HAVRÁNEK, BOHUSLAV - KŘísTEK, VÁCLAV - PETR, JAN. Academia, Praha, 1968-2008.

SSJ. = Slovník slovenského jazyka 1-6. Szerk. PECIAR, ŠTEFAN. Vydavatel'stvo SAV, Bratislava, 1959-1968.

SSN. = Slovnik slovenských náreči 1-2. [A-Povchádzat'.] Szerk. RIPKA, IVOR. Veda, Trenčín-Bratislava, 1994-2006.

SStp. = Słownik staropolski 1-11. Főszerk. URBAŃCZYK, STANISŁAW. Instytut Języka Polskiego Polskiej Akademii Nauk, Warszawa, 1953-2002.

SSuM. = Slovnyk staroukrajinśkoji movy XIV-XV st. 1-2. Főszerk. GUMEĆKA, LUKIJA LUKIJANIVNA - KERNYĆKYJ, IVAN MYCHAJLOVYČ. Наукова думка, Київ, 1977-1978.

STACHOWSKI, MAREK 2009. Eugen Helimskis Materialien zur Erforschung der ältesten slawisch-ungarischen Sprachkontakte. Studia Etymologica Cracoviensia 14: 35-107.

STACHOWSKI, MAREK 2014. Remarks on the investigation of the oldest layer of Turkic loan-words in Hungarian. Studia Etymologica Cracoviensia 19: 215-222.

SUM. = Slovnyk ukrajinśkoji movy 1-11. Főszerk. BILODID, IVAN. Naukova Dumka, Kyjiv, 1970-1980.

SW. = KARŁOWICZ, JAN - KRYŃSKI, ADAM ANTONI - NIEDŹWIEDZKI, WŁADYSŁAW 1904. Słownik języka polskiego 3. Nakładem prenumeratorów i Kasy im. Mianowskiego, Warszawa.

SWil. = CZEPIELIŃSKI, FLORIAN et al. 1861. Słownik języka polskiego 1-2. Orgelbrand Maurycy, Wilno.

SzófSz. = BÁRCZI GÉZA 1941. Magyar szófejtő szótár. [Hasonmás kiadás: Trezor Kiadó, Budapest, 1994.]

SzT. = Erdélyi magyar szótörténeti tár 1-14. Föszerk. SzABÓ T. ATTILA et al. Kriterion Könyvkiadó, Bucureşti [1-4.], Akadémiai Kiadó, Budapest [5-8.], Erdélyi MúzeumEgyesület, Kolozsvár [9-14.], 1975-2014.

TECHERT JózSEF 1936. Csokonai nyelvi forrásai. Magyar Nyelv 32: 110-117, 180-187, 237-248, 311-317.

TESz. = A magyar nyelv történeti-etimológiai szótára 1-3. Főszerk. BENKŐ LORÁND. Akadémiai Kiadó, Budapest, 1967-1976.

TLH. = RÓNA-TAS, ANDRÁS - † BERTA, ÁRPÁD (with the assistance of LÁSZLÓ KÁROLY) 2011. West Old Turkic. Turkic Loanwords in Hungarian 1-2. Turcologica 84. Harrassowitz Verlag, Wiesbaden.

TNyt. = A magyar nyelv történeti nyelvtana I-II/1-2. Főszerk. BENKÖ LORÁND. Akadémiai Kiadó, Budapest, 1991-1995.

Tolnai Vilmos 1929. A nyelvújitás. Magyar Tudományos Akadémia, Budapest.

TÖRÖK KATALIN 2007. Polonizmy w języku węgierskim. Prace Filologiczne 53: 629-636. TürS. = Türkçe Sözlük 1-2. Főszerk. EREN, HASAN. Türk Dil Kurumu, Ankara, 1988.

VÁMBÉRY ÁRMIN 1870. Magyar és török-tatár szóegyezések. Nyelvtudományi Közlemények 8: 109-189. 
VS. = Východnoslovenský slovnik 1-2. Szerk. HALAGA, ONDREJ RICHARD. Universum, Košice-Prešov, 2002.

ZOLTÁN ANDRÁS 1999. „Lappangó” szláv eredetü szavaink: szid, szégyen. Magyar Nyelv 95: 54-59.

ZOLTÁN, ANDRÁs 2010. К этимологии венгерского названия darázs 'оса шершень'. Studia Slavica Academiae Scientiarum Hungaricae 55/2: 471-473. http://dx.doi.org/[-] 10.1556/SSlav.55.2010.2.34

ZOLTÁN, ANDRÁs 2014. Einige Bemerkungen zu Lubor Králiks slawischer Etymologie von ung. vizsga, vizsgál. Studia Etymologica Cracoviensia 19: 211-213.

\section{A Slavonic approach to the etymology of Hung. ocsúdik 'awake, come to'}

The two different Turkic etymologies of Hung. ocsúdik (1508) 'awake, come to, regain consciousness' proposed in the late 19th century by Ármin Vámbéry (1870) and later by Margit K. Palló $(1976,1982)$ have been rightly rejected by the authors of TLH. At the same time, the explanation of the origin of this word we find in the etymological dictionaries of Hungarian (TESz, EWUng, Zaicz 2006), namely that it is a derivative from an unknown and unproductive stem, is not entirely convincing for morphological reasons. In the present paper a new etymology is offered for this word and it is explained as a loanword from East Slavonic очюдитися 'regain consciousness, awake' attested in Russian in the 16th-17th centuries.

Keywords: etymology, Hungarian etymology, Slavonic etymology, Slavonic loanwords in Hungarian, the adaptation process of loan-verbs in Hungarian.

NÉMETH MICHAŁ

Uniwersytet Jagielloński w Krakowie Johannes Gutenberg-Universität Mainz 